\section{The effects of a single high-dose injection of vitamin-D on healing of condylar fractures in osteoporotic rats}

\section{Osteoporotik sıçanlarda tek yüksek doz D-vitamini enjeksiyonunun kondil kırığı iyileşmesine etkisi}

\author{
Assist. Prof. Uğur Mercan \\ Okan University, Faculty of Dentistry, \\ Department of Oral and Maxillofacial Surgery, \\ Istanbul \\ Orcid ID: 0000-0003-4935-673X
}

Assist. Prof. Yonca Betil Kabak

Ondokuz Mayis University, , Faculty of Veterinary

Medicine, Department of Pathology,

Samsun

Orcid ID: 0000-0002-3442-8377

Assist. Prof. Akif Turer

Bulent Ecevit University, Faculty of Dentistry,

Department of Oral and Maxillofacial Surgery,

Zonguldak

Orcid ID: 0000-0003-1175-1670

Asoc. Prof. Osman Kelahmetoglu

Bezmi Alem University, Faculty of Medicine,

Department of Plastic and Reconstructive Surgery, Istanbul

Orcid ID: 0000-0003-1175-1670

Prof. Deniz Gokce Meral

Okan University, Faculty of Dentistry,

Department of Oral and Maxillofacial Surgery,

Istanbul

Orcid ID: 0000-0002-6651-2872

Geliș tarihi: 17 Temmuz 2018

Kabul tarihi: 18 Aralık 2018

doi: 10.5505/yeditepe.2019.83792

\section{Yazışma adresi:}

Corresponding Author:

Ugur MERCAN PhD, DDS,

Department of Oral and Maxillofacial Surgery, Faculty of Dentistry, Okan University, Istanbul, Turkey

Gulbahar Mh. Oya Sok. No: 23/A Mecidiyekoy - Sisli Istanbul/ Turkey 34394

Email: dr.umercan@yahoo.com

Phone: +90 5303291369

Fax Number: +90 2166771906

\section{SUMMARY}

Aim: In this study we have tried to show the effects of a single high-dose Injection of vitamin d on healing of condylar fractures in osteoporotic rats.

Materials and method: This study included sixteen female wistar rats. All rats were overiectomized. Osteoporotic rats were randomly divided into two groups of eight animals/ group. Group D animals received a single high dose of vita$\min \mathrm{D}(50.000 \mathrm{lU} / \mathrm{kg})$ intraperitoneally and group C (control) animals received saline $(0.05 \mathrm{~mL})$ intraperitoneally. All injections were given immediately after condylar fracture. All rats were euthanized after 28 days, examined histopathological and immunohistochemical.

Results: Histopathological and immunohistochemical evaluations were done. Histopathological scores between group $\mathrm{D}$ and $\mathrm{C}$ were found statistically significant. TGF $\beta 1$ and osteopentin levels in group $D$ were found higher than group $C$.

Conclusion: We have determined that a single high-dose injection of vitamin D given immediately after surgery increased TGF $\beta$ and osteopontin levels and enhanced new bone formation at condylar fractures of osteoporotic rats.

Keywords: Condylar fracture, osteoporosis, vitamin D, single dose

ÖZET

Amaç: Bu çalışmada, osteoporotik sıçanlarda kondiler kırıkların iyileşmesinde tek yüksek doz verilen D vitamininin etkilerini göstermeye çalıştık.

Gereç ve Yöntem: Bu çalışmada 16 dişi wistar sıçanı kullanıldı. Tüm sıçanlara overiektomi uygulandı. Osteoporotik sıçanlar rastgele her grupta sekiz hayvan olacak şekilde iki gruba ayrıldı. Grup D hayvanlarına intraperitoneal olarak tek doz D vitamini $(50,000 \mathrm{lU} / \mathrm{kg}$ ) verildi ve grup C (kontrol) hayvanlara intraperitoneal olarak serum fizyolojik $(0,05 \mathrm{~mL})$ verildi. Tüm enjeksiyonlar, kondiler kırıktan hemen sonra yapıldı. Bütün sıçanlar 28 gün sonra sakrifiye edildi, Histopatolojik ve immünohistokimyasal olarak incelendi.

Bulgular: Histopatolojik ve immünohistokimyasal değerlendirmeler yapıldı. D ve C grubu arasındaki histopatolojik veriler istatistiksel olarak anlamlı bulundu. Grup D' de TGF $\beta 1$ ve osteopentin düzeyleri $C$ grubundan daha yüksek bulundu.

Sonuç: Cerrahi müdahaleden hemen sonra verilen tek yüksek doz D vitamini enjeksiyonunun, osteoporotik sıçanların kondiler kırıklarında TGF $\beta$ ve osteopontin seviyelerini ve yeni kemik oluşumunu arttırdığını tespit ettik.

Anahtar kelimeler: Kondil kırığı, osteoporoz, D vitamini, tek doz

\section{INTRODUCTION}

Osteoporosis (literally: porous bone) is a systemic and metabolic disease of the skeletal system. The National Osteoporosis Foundation has identified some risk/predisposing factors for osteoporosis and related fractures. These include a history 
of fractures in adulthood, smoking, estrogen deficiency at an early age, low body weight, poor health, low calcium intake, physical inactivity, little exposure to sunlight, alcohol abuse, and the use of oral glucocorticoid therapy for more than 3 months in postmenopausal females. ${ }^{1,2}$ The disease is characterized by reduced bone density and quality, impairment of the bone microarchitecture, and reduced mechanical resistance. Such changes increase the risk of fracture. ${ }^{1}$ Pisani et al. reported that almost 200 million subjects worldwide are affected by osteoporosis, suffering 8.9 million fractures annually; fracture associated with osteoporosis is thus a major public health problem. ${ }^{2}$ The numbers of traumatic injuries in the elderly are increasing as advances in medicine are increasing human lifespan and populations feature ever-increasing proportions of older subjects, who seek to be as active as possible..$^{3-5}$ Chrcanovic et al. found that mandibular fracture was the most common type of facial fracture in those $>60$ years of age. ${ }^{4}$ Fractures of the mandibular condyle are thought to account for about $25-35 \%$ of all mandibular fractures. ${ }^{6,7}$ After direct mandibular trauma, indirect forces are transmitted to the condyle, and the weak condylar neck breaks easily to protect the brain from damage. ${ }^{8}$ Many substances affect the time required for fracture healing. These include biphosphonates, hormones, and growth factors that exert different effects. ${ }^{9-11}$ Earlier studies showed that vitamin D3 promoted fracture healing. ${ }^{12-15}$

Positive effect of vitamin D on bone; it increases TGF synthesis and release, regulates osteoblast differentiation, stimulates tissue repair and osteocalcin and osteopontin production. ${ }^{16-21}$ Although many recent studies have evaluated the effects of vitamin $D$ on fracture healing in general, the effects of vitamin D injection on condylar fracture healing, particularly in osteoporotic patients, have been but rarely investigated. We aimed to evaluate the positive effect of vitamins on the condyle fractures treated with closed reduction of the patients with high risk of poor recovery such as advanced age, metabolic or primary bone diseases or malnoutrevulation. In the present study we sought to accelerate healing of condylar fractures in osteoporotic rats. We used immunohistochemical and histological techniques to evaluate the effectiveness of the treatment.

\section{MATERIALS AND METHOD}

The study was approved by the Animal Experimentation Committee of Bülent Ecevit University, Zonguldak, Turkey. The surgical procedures for this research were performed according to protocols approved by the animal care and ethics committee of Bulent Ecevit University (protocol number: 2016-33-02/06). This study included sixteen female Wistar rats 6-8 weeks of age $(250-300 \mathrm{~g})(\mathrm{n}=16)$ were housed in standard cages in rooms of relative humi- dity $40-60 \%$ at $22 \pm 1^{\circ} \mathrm{C}$ under a 12-h:12-h light/dark cycle. All rats were overiectomized. Osteoporotic rats were randomly divided into two groups of eight animals/group. Group D animals received a single high dose of vitamin D $(50.000 \mathrm{lU} / \mathrm{kg})$ intraperitoneally and group C (control) animals received saline $(0.05 \mathrm{~mL})$ intraperitoneally.

Ovariectomy

Weights were digitally measured prior to ovariectomy. Each rat was anesthetized via intramuscular injection of 3 mg xylazine hydrochloride (Rompuns; Bayer, Leverkusen, Germany)/kg and $35 \mathrm{mg}$ ketamine hydrochloride (10\% [w/v] Ketasol; Richter Pharma AG, Wels, Austria) $/ \mathrm{kg}$. The dorsal part of the lumbar region was shaved and cleaned with $10 \%(\mathrm{v} / \mathrm{v})$ povidone iodine. A 2-cm-long mid-dorsal skin incision was made caudal to the posterior border of the ribs. After dissection of the abdominal muscles (the $\mathrm{m}$. obliques externus abdominis and the $\mathrm{m}$. obliques internus abdominis) and the membrane, the omentum was displaced. The ovaries were sutured, commencing at the meso-ovarium proximally and extending to the cornu uteri distally, employing resorbable $4 / 0$ polyglycolide-co-lactide (Vicryl; Ethicon, Somerville, NJ, USA). Both ovaries were removed and the muscles and deep tissues sutured with resorbable material. The skin was closed using 3/0 silk sutures (Medeks, Istanbul, Turkey). After ovariectomy, each animal was injected with $10 \mathrm{mg}$ cefazolin sodium (Sefazol; M Nevzat, Istanbul, Turkey)/kg and 200 mg metamizol sodium (Novalgin; Aventis, Istanbul, Turkey)/kg on each of the next 5 days to control infection and provide analgesia. We monitored wound-healing, feeding behavior, systemic health, and activity levels. At the 6-week follow-up period, no rat had any local infection or obvious pathology, but all rats were now osteoporotic. ${ }^{22,23}$

\section{Experimental groups}

Osteoporotic rats were randomly divided into two groups of eight animals/group. Group $D$ animals received a single high dose of vitamin D (Devit D3 300,000 IU/1 mL from one ampule, Deva, Istanbul Turkey) $(50.000 \mathrm{lU} / \mathrm{kg})$ intraperitoneally and group $\mathrm{C}$ (control) animals received saline $(0.05 \mathrm{~mL})$ intraperitoneally. All injections were given immediately after condylar fracture.

\section{Surgical procedure}

All surgery was performed under aseptic conditions in the operation room of an animal laboratory. All surgical procedures were performed under general anesthesia as in the ovariectomy procedure. A $10-\mathrm{mm}$-long pre-auricular incision was made directly below the zygomatic arch, followed by blunt dissection through the masseter muscle, and the condylar process was exposed. The condyle was fractured at the subcondylar neck using a mosquito forceps to deviate the condylar fragment medially (Fig. 1). The flaps were sutured with resorbable $4 / 0$ polyglycolide-co-lactide (Vicryl; Ethicon, Somerville, NJ, USA). After 
fracture, the animals were injected as described above. The same antimicrobial and analgesic drugs were used to allow of postoperative infection control and analgesia. Each animal was injected with $10 \mathrm{mg}$ cefazolin sodium/ $\mathrm{kg}$ and $200 \mathrm{mg}$ metamizol sodium/ $\mathrm{kg}$ on each of 5 days after operation.

\section{Histopathology}

All rats were euthanized by lethal anesthetic injection after 28 days. After skin dissection, the mandibles were harvested, fixed in $10 \%(\mathrm{v} / \mathrm{v})$ neutral buffered formalin for 2 days, decalcified in a formic acid/sodium citrate solution for 3 weeks, dehydrated by passage through a series of graded alcohol bath, cleared with xylene, and embedded in paraffin. Coronal bone sections ( $5 \mu \mathrm{m}$-thickness) were prepared and stained with hematoxylin-eosin (HE). The bone formation at the fracture gap was scored according to the method described by Tatli et al. ${ }^{24}$ The details of the scoring method were shown in Table 1.

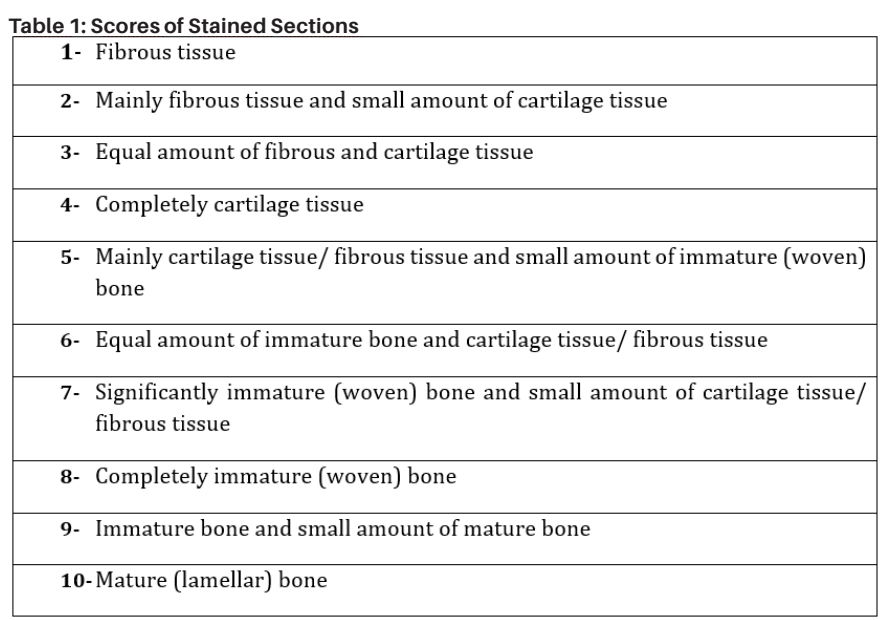

Immunohistochemistry (IHC)

Bone sections (5 $\mu \mathrm{m}$-thickness) were subjected to immunohistochemistry $(\mathrm{IHC})$ using the streptavidin/ biotin peroxidase complex $(\mathrm{SABC})$ technique to detect bone morphogenetic protein-2 (BMP-2), transforming growth factor beta (TGF $\beta$ ), and osteopontin. Serial sections were dewaxed in xylene and hydrated through a series of graded alcohol baths Endogenous peroxidase activity was blocked by addition of $3 \%(\mathrm{v} / \mathrm{v}) \mathrm{H}_{2} \mathrm{O}_{2}$ in methanol for 15 min. The sections were rinsed with phosphate-buffered saline (PBS, $\mathrm{pH}$ 7.2) and a proteinase solution added for $15 \mathrm{~min}$ at $37^{\circ} \mathrm{C}$. After washing with PBS, the sections were pre-incubated in $10 \%(\mathrm{v} / \mathrm{v})$ rat nonimmune serum (Thermo Scientific; Fremont, CA, USA) at room temperature for 10 min and then with primary antibodies against BMP2 (NBP1-19751, Novus Biologicals), TGF $\beta 1$ (sc-146, Santa Cruz Biotechnology), or anti-osteopontin (ab8448, Abcam) for $1 \mathrm{~h}$, and rinsed with PBS at room temperature. The sections were next incubated with a biotinylated goat anti-polyvalent antibody (Thermo Scientific) for $20 \mathrm{~min}$ and rinsed in PBS. Streptavidin peroxidase was added for $10 \mathrm{~min}$ at room temperature. Labelling was visualized using 3-amino-9-ethylcarbazole (Thermo Scientific) as the chromogen. The sections were briefly counterstained with Meyer's haematoxylin. The negative controls were samples for which the primary antibodies were replaced with normal goat serum.

\section{Immunohistochemical evaluation}

The immunohistochemical results were interpreted using a light microscope (Nikon Eclipse E600, Nikon, Japan). Semi-quantitative evaluation of stained sections was performed on areas of interest only. Staining intensities were evaluated semi-quantitatively ( 0 , negative; 1 , weak; 2 , moderate; 3 , strong) and by calculating the ratios of stained to total areas $(0$, nil; $1,<25 \% ; 2,26-75 \% ; 3,>76 \%)$. All quantification was performed by the same pathologist.

\section{Statistical analysis}

All statistical analysis was performed with the aid of IBM SPSS Statistics version 22 (IBM SPSS, Turkey); the Mann-Whitney U-test (a descriptive method) was used to compare all data. A p-value $<0.05$ was considered to reflect statistical significance.

\section{RESULTS}

\section{Histopathological evaluation}

Control group (group C)

The fracture margins of the control group were not closed. Hematomas and inflammatory cells were evident between fracture margins, as were connective tissue bridges. The connective tissue contained primitive mesenchymal cells. Periosteal reactions were observed only at the fracture margins. New blood vessels were evident between trabeculae but myeloid cells were absent (Fig. 2 A).

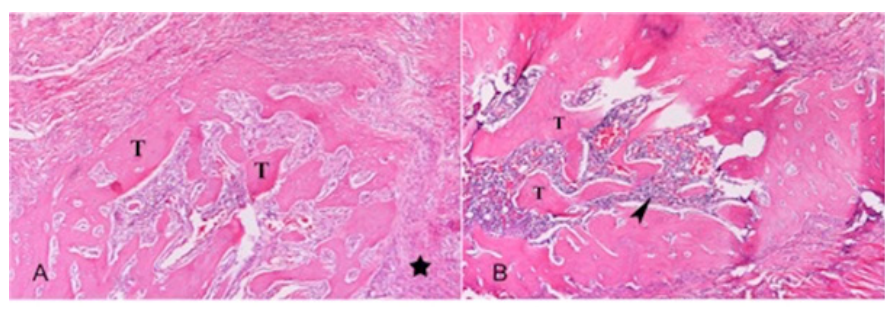

Figure 2: Histological sections showing bone healing at the fracture by hematoxylin and eosin stain A: Sample from the control group. B: Sample from the vitamin D group. $T$; trabecular, P; periosteum, $\star$; primitive mesenchymal cells, $>$; myeloid cell.

\section{Experimental group (group D)}

The fracture margins were almost closed and intramembranous ossification was apparent. The extent of periosteal cell proliferation at the fracture margins and around new bones was higher than that of the control. Blood vessels, myeloid cells, and primitive mesenchymal cells were evident between the trabeculae (Fig. 2 B). The histopathological scores of groups $D$ and $C$ were $7.25 \pm 1.58$ and $4.13 \pm 1.96$ respectively; the difference was statistically significant ( $p-0.003 ; p<0.01$ ) (Table 2). 
Table 2: Comparison of Histologic Data

\begin{tabular}{lcc}
\cline { 2 - 3 } & Mean \pm SD & Medyan (Min-Max) \\
\hline \hline Group D (Vitamin D) & $7,25 \pm 1,58$ & $7(5-9)$ \\
Group C (Control) & $4,13 \pm 1,96$ & $5(1-6)$ \\
\hline $\boldsymbol{p}$ & & $\mathbf{0 , 0 0 3}$ ** \\
\hline Mann Whitney UTest & ** $p<0,01$ &
\end{tabular}

Immunohistochemical evaluation

BMP-2

New bone, and the endosteal osteoblasts around the trabeculae and periosteal regions, were weakly immunopositive for BMP-2 in both groups. Neither the BMP-2 intensity nor area stained differed between the two groups $(p=0.264 ; p>0.05)$ (Fig. 3, Table 3).

Table 3: Comparison of Immunohistochemical Data

\begin{tabular}{|c|c|c|c|c|}
\hline & \multirow{2}{*}{$\begin{array}{l}\text { Vitamin D } \\
\text { Mean } \pm \text { SD } \\
\text { Median(Min-Max) }\end{array}$} & \multirow{2}{*}{$\begin{array}{c}\text { Control } \\
\text { Mean } \pm \text { SD }\end{array}$} & \multirow[t]{2}{*}{$p$} \\
\hline & & & & \\
\hline \multirow[t]{2}{*}{ BMP 2} & Stained Area & $\begin{array}{l}1,38 \pm 0,52 \\
1(1-2)\end{array}$ & $\begin{array}{l}1,13 \pm 0,35 \\
1(1-2)\end{array}$ & 0,264 \\
\hline & Staining Intensity & $\begin{array}{l}1,25 \pm 0,46 \\
1(1-2)\end{array}$ & $\begin{array}{l}1,13 \pm 0,35 \\
1(1-2)\end{array}$ & 0,535 \\
\hline \multirow[t]{2}{*}{ TGF- $\beta$} & Stained Area & $\begin{array}{l}2,5 \pm 0,53 \\
2,5(2-3)\end{array}$ & $\begin{array}{l}0,25 \pm 0,46 \\
0(0-1)\end{array}$ & $0,001^{* *}$ \\
\hline & Staining Intensity & $\begin{array}{l}2 \pm 02 \\
(2-2) \\
\end{array}$ & $\begin{array}{l}0,25 \pm 0,46 \\
0(0-1) \\
\end{array}$ & $0,001^{* *}$ \\
\hline \multirow[t]{2}{*}{ Osteopontin } & Stained Area & $\begin{array}{l}2,88 \pm 0,35 \\
3(2-3)\end{array}$ & $\begin{array}{l}1,25 \pm 1,04 \\
2(0-2)\end{array}$ & $0,001^{\star *}$ \\
\hline & Staining Intensity & $\begin{array}{l}2,5 \pm 0,53 \\
2,5(2-3)\end{array}$ & $\begin{array}{l}0,63 \pm 0,52 \\
1(0-1)\end{array}$ & $0,001^{\star *}$ \\
\hline
\end{tabular}

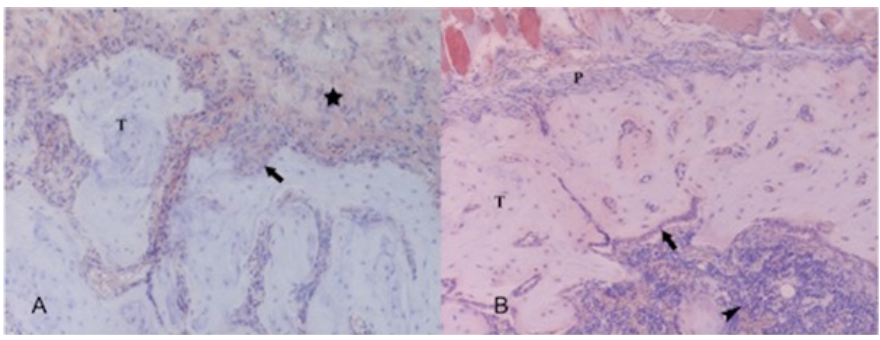

Figure 3: Histological sections showing bone healing at the fracture by BMP-2 immuno-

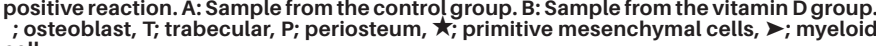
cell.

TGF $\beta 1$

Primitive cells between the trabeculae, endosteal osteoblasts, and periosteal cells reacted positively with the anti-TGF $\beta 1$ antibody in group D. However, in the control group, only one sample was positive. The TGF $\beta 1$ staining density, and the area stained, were significantly higher in group D than group C ( $p=0.001 ; p<0.01)$ (Fig. 4, Table 3).

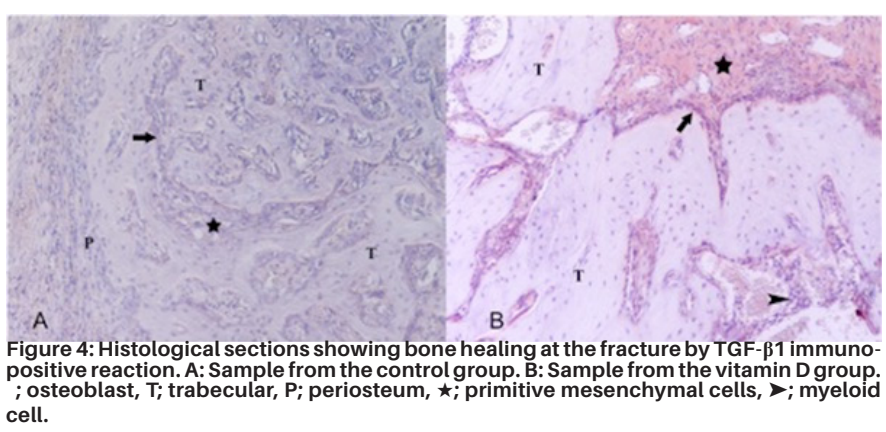

\section{Osteopontin}

In group $D$, the cytoplasms of osteoblasts around new trabeculae, that of primitive mesenchymal cells, and that of cells in the periosteal regions, were immunopositive for osteopontin. In group C, the primitive cells between fracture margins and the periosteal cells stained only weakly; the differences were significant $(p=0.001 ; p<0.01)$ (Fig. 5, Table 3).

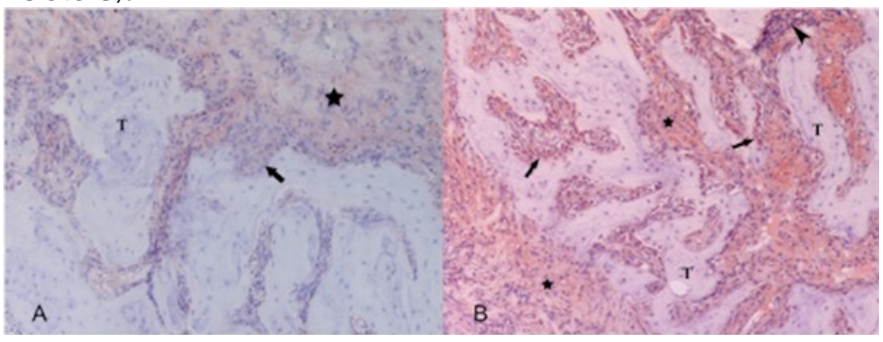

Figure 5: Histological sections showing bone healing at the fracture by osteopontin im munopositive reaction. A: Sample from the control group. B: Sample from the vitamin D group. $\bowtie$; osteoblast, $\mathrm{T}$; trabecular, $\mathrm{P}$; periosteum, $\star$; primitive mesenchymal cells, $>$ myeloid cell.

\section{DISCUSSION}

In this study, we aimed to evaluate the positive effect of vitamins on the condyle fractures treated with closed reduction of the patients with high risk of poor recovery such as advanced age, metabolic or primary bone diseases or malnoutrevulation.

Fractures associated with osteoporosis are a major public health problem associated with morbidity, impairment, a decrease in the quality-of-life, and mortality, in both females and males. Approximately $50 \%$ of females and $25 \%$ of males $\geq 50$ years of age will experience an osteoporotic fracture in their lifetimes. Given this global problem, we studied fracture healing in ovariectomized (osteoporotic) rats. Pisani et al. reviewed factors associated with osteoporotic fracture risk; these included a low body mass index, a history of fragility fractures, environmental risks, early menopause, smoking, lack of vitamin $D$, endocrine disorders, use of glucocorticoids, and excessive alcohol intake. $^{2}$ As lifespan has increased, the quality-of-life has also improved, allowing the elderly to be more physically active but, thus, increasing the risk of injury. Gerbino et al. described 2,235 patients hospitalized over a 10-year interval to treat fractures in the maxillofacial region. ${ }^{3}$ Of these, 222 were aged 60-91 years. Over time, the prevalence of maxillofacial trauma in elderly patients increased from 7 to $12 \% .^{3}$

Mandibular fractures are the most common fractures of the maxillofacial region that constitute $24-78 \%$ of all maxillofacial fractures, ${ }^{25,26}$ whereas condylar fractures constitute $25-35 \%$ of all mandibular fractures. ${ }^{6,7}$ Yamamoto et al. retrospectively analyzed trends in, and the characteristic features of maxillofacial fractures in older patients. ${ }^{5}$ The cited authors collected data from 247 patients aged $\geq 65$ years treated for maxillofacial fractures from 1981 to 2010. Of all maxillofacial fractures, $56.7 \%$ were in the mandible. Condylar fractures were the most common (64.6\%) mandibular fractures in elderly patients. ${ }^{5}$

No area of the mandible is as controversial as the condylar region in terms of appropriate choise of treatment. The 
treatment should include a non-chew diet alone or as an additional treatment following the maxillomandibular fixation, in patients whom open reduction of the condyle is not indicated. ${ }^{27}$ Patients without significant displacement of the fracture segments are best treated with closed reduction and a short period of immobilization. Patients at high risk for poor healing such as advanced age, metabolical or primary bone diseases or malnoutrishment have also a greater risk of ankylosis, malunion or nonunion. ${ }^{27}$ Studies related with osteoporosis have shown that bone healing to be prolonged with decreased levels of mesenchymal stem cells and decreased levels of angiogenesis. $^{28}$

Because of the negative effects of the osteoporosis on the bone healing we prefered ostoeporotic rat model for this study. In this study, we aimed to evaluate the positive effect of vitamins on the condyle fractures treated with closed reduction of the patients with high risk of poor recovery such as advanced age, metabolic or primary bone diseases or malnoutrevulation. In the present study we sought to accelerate healing of condylar fractures in osteoporotic rats. Studies showed that adult female rats underwent bilateral ovariectomy and became osteoporotic 6 weeks later. ${ }^{22,23}$

In the literatüre it was already shown the effect of experimental ovariectomy on osteoporosis. The duration to see influence of bone loss after ovariectomy should be 2 weeks at least. ${ }^{29,30}$

Subsequently, unilateral condylar fractures were created using the method of Cavalcanti et al. ${ }^{31}$ The time required for fracture healing ${ }^{32}$ is affected by the levels of growth factors and hormones, osteogenic cells and osteoconductive scaffolds, the mechanical environment (the stability of fixation), and other parameters including the levels of anti-dickkopf-1 and anti-sclerostin antibodies, prostaglandin E2 receptor agonists, vitamins $\mathrm{C}, \mathrm{D}$ and $\mathrm{E}$, and thrombin-related peptide (TP508) (which enhances bone healing) ${ }^{11}$ The various factors influence bone healing differently, modulating calcium absorption, angiogenesis, collagen deposition, osteoblast stimulation, and bone remodeling. ${ }^{9,10}$ Some studies found that vitamin D promoted fracture healing by playing a major role in calcium metabolism; adequate vitamin $D$ is essential for skeletal health. ${ }^{33}$ Guidelines for the management of postmenopausal osteoporosis suggest that vitamin D sufficiency is important to ensure an optimal response to treatment. ${ }^{34,35,36}$ Lips et al. studied 2,606 postmenopausal females with osteoporosis (from 18 countries) and found that $64 \%$ had inadequate levels of vitamin $D .{ }^{33}$ Lack of vitamin $D$ was a major risk factor for postmenopausal osteoporosis. A multidisciplinary clinical study found that vitamin $\mathrm{D}$ deficiency was common, being evident in $57-82 \%$ of postmenopausal osteoporotic females. ${ }^{33}$ Mezquita-Raya et al. showed that vitamin D insufficiency was a common risk factor for osteoporosis associated with increased bone remodeling and low bone mass in postmenopausal populations. ${ }^{37}$ Pisani et al. found that vitamin $\mathrm{D}$, calcium, and protein insufficiencies were very common in the elderly. ${ }^{2}$ In adults, vitamin D deficiency exacerbates osteopenia and osteoporosis. Insufficient vitamin D reduces bone mineral density and bone strength, increasing the risk of instability when mobile. ${ }^{38}$ Vitamin $D$ insufficiency negatively affects calcium metabolism, osteoblast activity, matrix ossification, bone mineral density (BMD), and bone remodeling. ${ }^{39,40}$ The need for increased vitamin D intake in females with postmenopausal osteoporosis has been emphasized. ${ }^{33,41}$ Vitamin D was required for hard callus formation and bone remodeling; Gorter et al. showed that future research should focus on vitamin $D$ supplementation to aid fracture healing. ${ }^{15}$ The role of vitamin $D$ in fracture healing has been studied in various animal models and with different application of vitamin D. ${ }^{13,42,43}$ In this study we preferred to intraperitoneally injected a single high dose of vitamin D application, as did Omeroglu et al. ${ }^{13}$ Vitamin $D$ increased the synthesis and release of TGF $\beta 20$ and upregulated the expression levels of TGF $\beta$ receptors I and II by osteoblasts. 16,19,21 TGF $\beta 1$ regulates osteoblast differentiation and plays a key role in tissue repair. ${ }^{17,18} \mathrm{We}$ found that TGF $\beta 1$ expression was significantly higher in the group $D$ than the control group, consistent with earlier results. Van Leeuwen et al. showed that production of osteocalcin and osteopontin by osteoblasts was stimulated by vitamin D. ${ }^{19}$ We found that osteopontin expression was significantly higher in the group $D$ than control group, again consistent with earlier results. Also, we found that the proliferation of all of periosteal cells, blood vessels, myeloid cells, and primitive mesenchymal cells lying between trabeculae, were significantly higher in the group $D$, in line with the results of prior studies. ${ }^{13,14,43}$ Positive effect of vitamin D on bone; It increases TGF synthesis and release, regulates osteoblast differentiation, stimulates tissue repair and osteocalcin and osteopontin production. ${ }^{16-21}$

The use of vitamin $D$ to accelerate fracture healing will allow an early return to daily activity by, and reduce the morbidity of, patients with condylar fractures associated with osteoporosis. We explored the effects of a single high-dose systemic injection of vitamin D on condylar fracture healing in osteoporotic rats.

The use of a single dose of vitamin $D$ in the clinic may be beneficial because of the favorable effect of vitamin $D$ on condyle fractures treated with closed reduction and reduce complication of the patients with a high risk of poor recovery, such as advanced age, metabolic or primary bone diseases or malnoutrevulation. 


\section{CONCLUSION}

We found that a single high-dose injection of vitamin $D$ given immediately after surgery increased TGF $\beta$ and osteopontin levels and enhanced new bone formation at condylar fractures of osteoporotic rats. The exact role played by vitamin $D$ in these contexts remains unclear; more clinical study should research positive effect of vitamin $D$ supplementation on fracture healing.

\section{References}

1.NIH Consensus Development Panel on Osteoporosis Prevention, Diagnosis, and Therapy. Osteoporosis prevention, diagnosis, and therapy. JAMA 2001;285:785-95. 2.Pisani P, Renna MD, Conversano F, Casciaro E, Di Paola M, Quarta E, Muratore M, Casciaro S. Major osteoporotic fragility fractures: Risk factor updates and societal impact. World J Orthop 2016;18:171-81

3.Gerbino G, Roccia F, De Gioanni PP, Berrone S. Maxillofacial trauma in the elderly. J Oral Maxillofac Surg 1999; 57:777-782.

4.Chrcanovic BR, Souza LN, Freire-Maia B, Abreu MH. Facial fractures in the elderly: a retrospective study in a hospital in Belo Horizonte, Brazil. J Trauma 2010;69:E73-8.

5.Yamamoto K, Matsusue Y, Murakami K, Horita S, Sugiura T, Kirita T. Maxillofacial fractures in older patients. J Oral Maxillofac Surg 2011;69:2204-10.

6.Manisali M, Amin M, Aghabeigi B, Newman L. Retromandibular approach to the mandibular condyle: a clinical and cadaveric study. Int $\mathrm{J}$ Oral Maxillofac Surg 2003;32:253-256.

7.Miloro M. Endoscopic-assisted repair of subcondylar fractures. Oral Surg Oral Med Oral Pathol Oral Radiol Endod 2003;96:387-91.

8.Oikarinen KS: Surgical versus nonsurgical treatment of unilateral dislocated low subcondylar fractures. Discussion. J Oral Maxillofac Surg 1994;52:360

9.Fini M, Aldini NN, Cane V, et al. Effects of essential amino acids and lactose on bony fractures and defects in rabbits: A preliminary histomorphometric study. Arch Orthop Trauma Surg 1999;119:39-45.

10.Jones CB. Biological basis of fracture healing. J Orthop Trauma 2005;19:1-3.

11.Claes $L$, Recknagel $S$, Ignatius $A$. Fracture healing under healthy and inflammatory conditions. Nat Rev Rheumatol 2012;8:133-43.

12. Andreen O, Larsson SE. Effects of parathyroidectomy and vitamin $\mathrm{D}$ on fracture healing. Fracture biomechanics in rats after parathyroidectomy and treatment with 1,25dihydroxycholecalciferol. Acta Orthop Scand 1983;54: 805-9.

13.Omeroglu $\mathrm{H}$, Ates $\mathrm{Y}$, Akkus $\mathrm{O}$, Korkusuz $\mathrm{F}$, Bicimoglu A, Akkas N. Biomechanical analysis of the effects of single high-dose vitamin D3 on fracture healing in a healthy rabbit model. Arch Orthop Trauma Surg 1997;116:271-4. 14.Omeroğlu S, Erdoğan D, Omeroğlu H. Effects of single high-dose vitamin D3 on fracture healing. An ultrastructural study in healthy guinea pigs. Arch Orthop Trauma Surg 1997;116:37-40.

15.Gorter EA, Hamdy NA, Appelman-Dijkstra NM, Schipper IB. The role of vitamin $D$ in human fracture healing: a systematic review of the literature. Bone 2014;64:288-97. 16.Wu Y, Haugen JD, Zinsmeister AR, Kumar R. 1 alpha,25-Dihydroxyvitamin D3 increases transforming growth factor and transforming growth factor receptor type I and II synthesis in human bone cells. Biochem Biophys Res Commun 1997;239:734-9.

17. Rameshwar P, Chang VT, Thacker UF, Gascón P. Systemic transforming growth factor-beta in patients with bone marrow fibrosis-pathophysiological implications. Am J Hematol 1998;59:133-42

18. Kassem M, Kveiborg M, Eriksen EF. Production and action of transforming growth factor-beta in human osteoblast cultures: dependence on cell differentiation and modulation by calcitriol. Eur J Clin Invest 2000;30:429-37. 19.Van Leeuwen JP, van Driel $\mathrm{M}$, van den Bemd GJ, Pols HA. Vitamin D control of osteoblast function and bone extracellular matrix mineralization. Crit Rev Eukaryot Gene Expr 2001;11:199-226.

20.Gurlek A, Pittelkow MR, Kumar R. Modulation of growth factor/cytokine synthesis and signaling by 1alpha,25-dihydroxyvitamin $D(3)$ : implications in cell growth and differentiation. Endocr Rev 2002;23:763-86.

21.Nagel D, Kumar R. 1 alpha, 25-dihydroxyvitamin D3 increases TGF beta 1 binding to human osteoblasts. Biochem Biophys Res Commun 2002;290:1558-63.

22.Boyd SK, Davison P, Müller R, Gasser JA. Monitoring individual morphological changes over time in ovariectomized rats by in vivo micro-computed tomography. Bone. 2006 Oct;39(4):854-62.

23.Pereira $M C$, Zecchin $K G$, Campagnoli $E B$, Jorge J. Ovariectomy delays alveolar wound healing after molar extractions in rats. J Oral Maxillofac Surg. 2007 Nov;65(11):2248-53.

24.Tatli $U$, Ustün $Y$, Kürkçü $M$, Erdoğan $O$, Gürbüz $C C$, Ozgür $\mathrm{H}$, Polat $\mathrm{S}$. Effects of zoledronic acid on healing of mandibular fractures: an experimental study in rabbits. $J$ Oral Maxillofac Surg 2011;69:1726-35

25.Gassner R, Tuli T, Hachl O, Rudisch A, Ulmer H. Cranio-maxillofacial trauma: A 10 year review of 9,543 cases with 21,067 injuries. J Craniomaxillofac Surg 2003;31:5161.

26. Erol B, Tanrikulu R, Gorgun B. Maxillofacial fractures. Analysis of demographic distribution and treatment in 2901 patients (25-year experience). J Craniomaxillofac Surg 2004;32:308-313.

27.Cizmeci MO, Karabulut A. Fractures of the mandıble 
and prıncıples of theır treatment. Ulus Travma Acil Cerrahi Derg. 1999; 5(3): 139-146

28.Cheung WH, Miclau T, Chow SK, Yang FF, Alt V. Fracture healing in osteoporotic bone. Injury. 2016 Jun;47 Suppl 2:S21-6.

29. Luize DS, Bosco AF, Bonfante S and de Almeida JM: Influence of ovariectomy on healing of autogenous bone block grafts in the mandible: A histomorphometric study in an aged rat model. Int J Oral Maxillofac Implants.2008; 23: $207-214$.

30.Comelekoglu U, Bagis S, Yalin S, Ogenler O, Yildiz A, Sahin NO, Oguz I and Hatungil R: Biomechanical evaluation in osteoporosis: Ovariectomized rat model. Clin Rheumatol.2007; 26: 380-384.

31.Cavalcanti SC, Corrêa L, Mello SB, Luz JG. The effect of methotrexate on the bone healing of mandibular condylar process fracture: an experimental study in rats. J Craniomaxillofac Surg 2014;42:1133-9.

32.Schindeler A, McDonald MM, Bokko P, Little DG. Bone remodeling during fracture repair: The cellular picture. Semin Cell Dev Biol 2008;19:459-66.

33. Lips P, Hosking D, Lippuner K, Norquist JM, Wehren L, Maalouf G, Ragi-Eis S, Chandler J. The prevalence of vitamin D inadequacy amongst women with osteoporosis: an international epidemiological investigation. J Intern Med 2006;260:245-54.

34.Sambrook PN, Seeman E, Phillips SR, Ebeling PR. Preventing osteoporosis: outcomes of the Australian Fracture Prevention Summit. Med J Aust 2002;176:S1-16.

35.Scottish Intercollegiate GN. Guidelines Network. 71. Management of Osteoporosis. Edinburgh, Scotland: Royal College of Physicians, 2003:1-46.

36.Boonen S, Body JJ, Boutsen Y. Evidence-based guidelines for the treatment of postmenopausal osteoporosis: a consensus document of the Belgian Bone Club. Osteoporos Int 2005; 16: 239-54.

37.Mezquita-Raya P, Muñoz-Torres M, Luna JD, Luna V, Lopez-Rodriguez F,Torres-Vela E, Escobar-Jiménez F. Relation between vitamin $\mathrm{D}$ insufficiency, bone density, and bone metabolism in healthy postmenopausal women. J Bone Miner Res 2001;16:1408-15.

38.Perez-Lopez FR. Vitamin D and its implications for musculo-skeletal health in women: an update. Maturitas 2007;58:117-137.

39.Villareal DT, Civitelli R, Chines A, Avioli LV. Subclinical vitamin $D$ deficiency in postmenopausal women with low vertebral bone mass. J Clin Endocrinol Metab 1991;72:628-34.

40. Khaw KT, Sneyd MJ, Compston J. Bone density parathyroid hormone and 25 hydroxyvitamin D concentrations in middle aged women. BMJ 1992;305:273-7

41.Gorter EA, Krijnen P, Schipper IB. Vitamin D deficiency in adult fracture patients: prevalence and risk factors. Eur
J Trauma EmergSurg 2016;42:369-78.

42. Lindgren JU, Narechania RG, McBeath AA, Lange TA, DeLuca HF. Effects of 1,24 dihydroxyvitamin D3 and calcitonin on fracture healing in adult rats. Clin Orthop Relat Res 1981;160:304-8.

43. Lidor C, Dekel S, Hallel T, Edelstein S. Levels of active metabolites of vitamin D3 in the callus of fracture repair in chicks. J Bone Joint Surg Br 1987;69:132-6. 